\title{
THE ROLE OF ETHIOPIAN COURTS IN COMMERCIAL ARBITRATION
}

\author{
Hailegabriel G. Feyissa*
}

\begin{abstract}
The role of arbitration in settling disputes which involves national and transnational commercial transactions is steadily growing in this era of globalisation. International and national rules governing various aspects of commercial arbitration have contributed to the effectiveness of arbitration as an alternative to litigation. The involvement of national courts is crucial to the overall efficacy of arbitration, both domestic and international. Instances calling for court intervention may appear at all stages of the arbitral proceedings. There is, however, a need to maintain a balance between the level of court involvement and the smooth functioning of arbitration - which is a contractual alternative to judicial dispute settlement. This article deals with the legal and practical role of Ethiopian courts during the three stages of arbitral proceeding, i.e., at the beginning of arbitration, during the arbitral proceedings, and after the end of the arbitration. And finally, I argue in favour of judicial restraint particularly during the first two stages of arbitral proceedings.
\end{abstract}

\section{Key words:}

Commercial Arbitration, Ethiopian courts, arbitral proceedings, judicial restraint

\section{Introduction}

Arbitration is seen here as a non-judicial dispute settlement mechanism whereby parties to a dispute resort to a third party (or parties) whose determination over the dispute is as binding as comparable court decisions. Depending on various factors, one can distinguish different types of arbitration. ${ }^{1}$ For instance, a distinction can be made between international and domestic arbitration. ${ }^{2}$ Within

* LL.B, LL.M, Lecturer in Law, Bahir Dar University School of Law.

- The author is grateful to Jennifer Ward and the anonymous reviewers for their comments which enriched the initial version of the work.

${ }^{1}$ See, e.g., Kröll, S. (2006) Arbitration, in Smits J. (ed.), Elgar Encyclopaedia of Comparative Law. Cheltenham, Edward Elgar Publishing Limited, p. 78 [hereinafter Kröll].

${ }^{2}$ See n. 29 infra and the accompanying text. 
the domain of international arbitration, one may further distinguish between investment arbitration, commercial arbitration and arbitration between states. ${ }^{3}$

For the purpose of this article, commercial arbitration stands for arbitration of commercial disputes between private parties to either domestic or international transactions. I intend to use international commercial arbitration to refer to arbitration between Ethiopians, on the one hand, and private parties from foreign nations, on the other. ${ }^{4}$

This article mainly focuses on commercial arbitration - both domestic and international. Particularly, it deals with the role played by Ethiopian courts in commercial arbitration. It argues that Ethiopian courts should maintain a friendly attitude towards commercial arbitration.

The first section of the article highlights the different approaches regarding the role of courts in arbitration and examines the reasons why Ethiopian courts should retain a minimalist approach regarding commercial arbitration. The second and third sections deal with the historical and present state of the Ethiopian legal regime on arbitration. And, the fourth section takes us through the crux of the research, i.e. the practical role Ethiopian courts have thus far played in commercial arbitration and its impact on the efficacy of the latter.

\section{The Interaction of Courts and Arbitral Tribunals: The Competing Approaches}

Arbitration as a dispute settlement device has a history dating as far back as ancient civilisations in Egypt and Greece. ${ }^{5}$ Literature indicates that arbitration predates litigation. ${ }^{6}$ The gradual prominence of governmental dispute settlement bodies led to a period of judicial hostility towards arbitration. In what are now "arbitration friendly" jurisdictions like the USA, Great Britain and France, there was a long-standing jurisprudence against arbitration. ${ }^{7}$ The main reason for the

${ }^{3}$ Kröll, supra n. 1, p. 78.

${ }^{4}$ But see n. 29 infra.

${ }^{5}$ Barrett, J. (2004) A History of Alternative Dispute Resolution. San Francisco, JosseyBass, pp. 1 et seq.; Zekos, G. (2008) International Commercial and Marine Arbitration. London, Routledge- Cavendish, pp. 9 et seq. [hereinafter Zekos].

${ }^{6}$ Zekos, ibid, p. 9.

${ }^{7}$ Martinez-Fraga, P. (2009) The American Influence on International Commercial Arbitration. Cambridge, Cambridge University Press, pp. 6-14[hereinafter MartinezFraga]; Navarro, P. Challenges of awards vis-á-vis the finality of international arbitration, pp. 11. Available from: <www.consulegis.com> [last accessed 31 Oct., 2010][hereinafter Navarro]; see also n. 45 infra. 
hostility between courts and arbitration was, inter alia, the belief that arbitration goes against public policy. ${ }^{8}$

Amidst this judicial attitude, however, the use and advantage of arbitration gained gradual ascendancy. Crucially, judicial prejudice against commercial arbitration has gradually faded away as the business sector "needed greater speed and flexibility for the settlement of their disputes than that provided by courts." Moreover, neutral venues in the form of international arbitral tribunals have been in demand as international trade grew dramatically after World War II. $^{10}$ This in turn led to gradual judicial accommodation of arbitration.

The traditional scepticism of arbitration now appears to have given way to remarkable judicial restraint. Yet, states have always kept arbitration under a certain level of court control. The desirability of a level of judicial assistance to and control over arbitration is now well understood. ${ }^{11}$ Nonetheless, a comparative analysis of national rules on commercial arbitration would reveal that the level of interaction between courts and arbitral tribunals varies from jurisdiction to jurisdiction. ${ }^{12}$

The most prevailing international trend confines judicial intervention to a minimum. ${ }^{13}$ This minimalist approach is represented by the United Nations Commission of International Trade Law Model Law on International Commercial Arbitration (UNCITRAL Model Law) and other comparable national arbitration laws. Aspects of this approach include the enforcement of arbitration agreements, the recognition of the principles of severability and competence-competence (Kompetenze-Kompetenze), the upholding of the finality of arbitral awards subject to certain fairness standards, the relative autonomy of arbitration from judicial intervention during the arbitral proceeding, and the enforcement of arbitral awards. Whereas, the maximalist approach is characterised by, for instance, the subjection of arbitral awards to

${ }^{8}$ In the common law jurisdictions, for example, arbitration was perceived to be against public policy for it "ousted otherwise competent courts of their jurisdiction"; see Martinez-Fraga, p. 7.

9 Zekos, supra n. 5, pp. 16-20.

${ }^{10}$ Craig, W. (1995) "Some Trends and Developments in the Laws and Practice of International Commercial Arbitration," Texas International Law Journal, (30), p. 2 [hereinafter Craig].

${ }^{11}$ See generally discussions under section 4 infra.

${ }^{12}$ See generally Zekos, supra n. 5 for an excellent comparative analysis of the role of English, US, Greek and Belgian courts in commercial arbitration.

${ }^{13}$ See, e.g., Gu, W. (2009-2010) "Judicial Review Over Arbitration in China: Assessing the Extent of the Latest Pro-Arbitration Move by the Supreme People's Court in the People's Republic of China", Wisconsin International Law Journal, (27), pp. 225-231; Kröll, supra n. 1, p.78. 
broader judicial review and the wider court intervention during the proceedings of the arbitration.

The challenge of maintaining a fair balance between "excessive judicial interference and necessary intervention" looks like an ever-ending endeavour as the minimalist-maximalist debate still continues with regard to judicial review of certain awards involving the application of such areas of law as antitrust. ${ }^{14}$

In this article, it is argued that Ethiopian courts must avoid excessive judicial interference with regard to commercial arbitration for the following reasons. First, arbitration is a method of dispute settlement which is based on the consent of parties to avoid litigation. Courts must not frustrate the parties' freedom of contract by interfering in the arbitration process and thus making the latter redundant. Second, arbitration - unhampered by excessive court interference is a desirable input for Ethiopia's attempt to actively participate in international trade and attract foreign investment. ${ }^{15}$ Third, courts themselves may benefit from abstaining from unnecessary intervention in commercial arbitration. ${ }^{16}$

\section{The Commercial Arbitration Regime of Ethiopia: Historical Overview}

The Ethiopian legal framework for modern arbitration was laid down by the codifications of the 1950s and 60s. Before that, arbitration was only known within the context of traditional dispute resolution processes. For the major part of Ethiopian legal history, non-judicial dispute settlement methods played a significant role in resolving disputes in a traditional Ethiopian society. Shimguilina is one of the many traditional Ethiopian dispute settlement devices which could be approximated to what is now known as arbitration. ${ }^{17}$

${ }^{14}$ Navarro, pp. 11 et seq.; see also Blanke, G. (2007) “The 'Minimalist' and 'Maximalist' Approach to Reviewing Competition Law Awards: A Never Ending Saga", Stockholm International Arbitration Review, (2), pp. 51-78.

${ }^{15}$ Asouzu A. lists numerous reasons why commercial arbitration is "an option of necessity and convenience for Africa in general; see Asouzu, A. (2001) International Commercial Arbitration and African States: Practice Participation and Institutional Development. (Cambridge: Cambridge University Press), pp. 27-50 [hereinafter Asouzu].

${ }^{16}$ Arbitrators should be seen as partners of judges in the administration of justice. They have a role to play in making the judiciary efficient by enabling the latter to avoid the unnecessary diversion of the limited judicial resources and time away from matters that require particular judicial attention.

17 Tilahun Teshome (2007), "The Legal Regime Governing Arbitration in Ethiopia." Ethiopian Bar Review, 1(2), pp. 117-118 [hereinafter Tilahun]; Brietzke, P. (1974) 
Nonetheless, shimguilina seems a much wider concept than the modern notion of "arbitration". The former combines aspects of different ADR mechanisms including mediation, conciliation, compromise and, of course, arbitration. ${ }^{18}$

Shimguilina, along with other forms of traditional dispute settlement processes, was well-liked by people living in rural Ethiopia - where access to state law enforcement organs used to be very limited. ${ }^{19}$ Apparently, it has also survived the transplantation of Western dispute settlement processes. Studies show that many people, including urban merchants, had widely used shimguilina "to save time and expense and to preserve business relations," even well after the transplantation of Western-style dispute settlement systems. ${ }^{20}$ This traditional alternative dispute settlement device is still popular among the $21^{\text {st }}$ century Ethiopian businesses, which often rely on it to settle disputes. ${ }^{21}$ Hence, arbitration has not been unknown to the traditional Ethiopian society.

The modern concept of commercial arbitration had, however, been alien to Ethiopia until at least mid-20 $0^{\text {th }}$ century, when Ethiopia developed most of its current codes on private law. Some provisions were made for arbitration in the 1960 Civil Code and the 1965 Civil Procedure Code (CPC). Articles 3325 to 3346 of the 1960 Civil Code govern the enforcement of agreements to arbitrate

"Private Law in Ethiopia," Journal of African Law, 18(2), p. 158 [hereinafter Brietzke].

${ }^{18}$ Tilahun, ibid, pp. 117-118; Fekadu Petros (2009), "Underlying Distinctions between ADR, Shimglina and Arbitration" Mizan Law Review, 3(1), p.124 [hereinafter Fekadu].

19 For a fair discussion on the prominence of non-judicial dispute settlement mechanisms among the traditional Ethiopian societies and the uneasy attempt of the State to impose modern legal institutions, see, e.g., Singer, N. (1970-1971) "A Traditional Legal Institution in a Modern Legal Setting: the Atbia Dagnia of Ethiopia", UCLA Law Review, 18, pp. 308 et seq.; Alula, Pankhurst \& Getachew Assefa (2008) Grass-roots Justice in Ethiopia: the Contribution of Customary Dispute Resolution. Addis Ababa, CFEE [hereinafter Alula \& Getachew].

${ }^{20}$ Brietzke, supra n. 17, p. 158 .

${ }^{21}$ See, e.g., a report by USAID (2007) Ethiopia Commercial Law \& Institutional Reform and Trade Diagnostic, p.60 [hereinafter USAID Report]; Mintwab Zelelew \& Mellese Madda (2008) Alternative Dispute Resolution in Addis Ababa: the Case of Markato, in ibid, Alula \& Getachew, p. 250. 
in the form of either arbitral clauses or submissions. ${ }^{22} \mathrm{CPC}$, for its part, provides rules on some procedural aspects of arbitration. ${ }^{23}$

Ethiopia is a signatory to the Convention on the Settlement of Investment Disputes between States and Nationals of Other States (ICSID Convention). ${ }^{24}$ Unlike many of its sub-Saharan counterparts, however, Ethiopia has not yet ratified the 1965 Convention to which it was one of the first signatories. Moreover, Ethiopia is yet to join the 1958 New York Convention on the Recognition and Enforcement of Foreign Arbitral Awards. ${ }^{25}$ As a result, the two codes, both of which predate the modern international arbitration legislation represented by UNCITRAL Model Law, are for now ${ }^{26}$ the major sources of arbitration law in Ethiopia.

Ethiopia's arbitration law seems "to be basically designed for domestic arbitration." 27 The pertinent provisions of the Civil Code and CPC do not distinguish, except in the context of execution of foreign arbitral awards, ${ }^{28}$ between domestic and international arbitration. It may thus appear that the Codes' provisions on arbitration do not apply to "international"29 arbitration.

${ }^{22}$ Appointment and replacement, disqualification, removal, competence and function of arbitrators along with effects of non-performance of arbitration agreement are generally governed by the 1960 Civil Code of Ethiopia [hereinafter Civil Code].

${ }^{23}$ In particular, procedure before arbitration tribunal, making of an award, appeal from, setting aside and execution of an award are governed by rules of the 1965 Civil Procedure Code of Ethiopia [hereinafter CPC].

${ }^{24}$ See the list of member states on the website of ICSID at $<$ www.worldbank.org/icsid $>$.

${ }^{25}$ Optimism on the eventual membership of Ethiopia to both the ICSID and New York Conventions surfaces as Ethiopia is now a member of regional trade zones which directly or indirectly encourage the adherence to such international conventions; see, in particular, Asouzu, p. 337.

${ }^{26}$ To the best of my knowledge, a new law on arbitration is set to be promulgated in the near future.

${ }^{27}$ Bezzawork Shimelash (1994) "The Formation, Content and Effect of an Arbitral Submission under Ethiopian Law" Journal of Ethiopian Law, 17, p. 90 [hereinafter Bezzawork].

${ }^{28}$ Note, however, that foreign arbitral award is not synonymous to international arbitral award. International arbitral awards may of course be domestic for the purpose of enforcement if the arbitral tribunal rendering the award has sat in the very jurisdiction where enforcement is sought.

${ }^{29}$ It is now uncommon for states to have two separate regimes of domestic arbitration and international arbitration. Initially, there was no distinction between international and domestic arbitration. According to one theory, the distinction has become relevant only after "the courts of various countries became involved in the conduct of arbitration and enforcement of arbitral awards". The jurisprudence in many jurisdictions indicates that the nationality of the parties, the international nature of the 
Such an argument would, however, be weighed down by the practical applicability of the Codes' provisions vis-à-vis international arbitrations sited in Ethiopia. $^{30}$

Incidentally, the term commercial which appears important in contemporary understanding of international commercial arbitration is irrelevant in so far as Ethiopian law on arbitration is concerned. For one thing, there is no law reserving arbitration to only commercial disputes as was the case in some traditional civil law countries. For another, Ethiopia is not a signatory to international treaties ${ }^{31}$ on recognition and enforcement of arbitral awards that allow commercial reservations - which would have necessitated a definition of commercial for that purpose.

A wider utilization of modern arbitration in Ethiopia has been delayed due to historical reasons. The reception of western style arbitration was not as revolutionary as the introduction of the law itself. ${ }^{32}$ First, one of the main reasons in the West for resorting to arbitration - the search for a dispute settlement mechanism other than the widely used courts - was initially missing in Ethiopia. ${ }^{33}$ Secondly, the poor utility of modern arbitration which ensued for

transaction and the place of arbitration are factors considered in deciding whether arbitration is international or not. Thus, international arbitration entails arbitration between (1) parties from different nations, (2) parties to an international transaction, or (3) parties to an arbitration agreement according to which a foreign place of arbitration is designated; see, e.g., Tweeddale, A. \& Tweeddale, K.. (2005) Arbitration of Commercial Disputes: International and English Law and Practice. Oxford, OUP, at § 2.27-2.28 [hereinafter Tweeddale \& Tweeddale]; Chiasson, E. (1999) A Comparison of International Arbitration Rules: the Practical Perspective. In: Campbell, D. \& Birkeland, B. eds. Lawyering in International Market. New York, Transnational Publishers Inc., pp. 339-341.

${ }^{30}$ See further discussions in section 4 infra.

${ }^{31}$ Such as the 1958 New York Convention on the Recognition and Enforcement of Foreign Arbitral Awards.

${ }^{32}$ See generally Beckstrom, J. (1973) "Transplantation of Legal Systems: an Early Report on the Reception of Western Laws in Ethiopia", American Journal of Comparative Law (21), p. 567 [hereinafter Beckstrom]; and Sedler, R. (1967-68) "The Development of Legal Systems: the Ethiopian Experience", Iowa Law Review 53 [hereinafter Sedler].

${ }^{33}$ In an article published few years after the 1960s codification, Robert Allen Sedler implicitly noted that Ethiopia was not as ready as its Western counterparts for arbitration or similar dispute resolution processes introduced by the law. He posits: "[unlike in Ethiopia], it is interesting to note that in countries with highly developed legal systems the trend is toward removing disputes from the courts and submitting them to arbitration and/ or giving jurisdiction to administrative tribunals"; see Sedler, p. 608 . 
some decades may also be attributed to "gross unfamiliarity" 34 with modern arbitration. ${ }^{35}$

Fortunately, recent developments show that Ethiopia has gradually developed an interest for alternative dispute settlement mechanisms including arbitration. ${ }^{36}$ Arbitration, along with other $\mathrm{ADR}^{37}$ mechanisms, is now a popular dispute settlement process among businesses - international or domestic. Inter alia, economic and time factors justify the growing popularity of ADR and arbitration. Litigating commercial disputes in courts is less favoured by parties because its financial burdens coupled with possible administrative barriers and corruption can "lead to distrust of courts". ${ }^{38}$ In particular, judicial settlement of international commercial disputes is usually unattractive to at least one of the parties who might find submitting disputes to national courts unpleasant. ${ }^{39}$

${ }^{34}$ Bezzawork states "...despite the fact that, we have elaborate and modern laws on arbitration (since 1960), there is still gross unfamiliarity with the meaning and application of arbitration"; see Bezzawork, supra note 27 p. 69.

35 In so far as international commercial arbitration is concerned, there has, however, long been a practice (among Ethiopian enterprises) of referring disputes [between them and counterparts in international commercial transactions] to renowned international arbitral bodies like the International Chamber of Commerce (ICC) in Paris. In particular, government enterprises submit their contractual disputes to arbitration; see, e.g., Re Baruch-Foster Corporation $v$ Imperial Ethiopian Government, reproduced in EACC Reports of Arbitral Awards, Vol.1 (EACC, Addis Ababa, 2008), at 1-11; Re Imperial Highway Authority v Solel Boneh Ltd., Supreme Imperial Court, Civil Appeal No.670/57, reproduced (in Amharic and English) in 2 Journal of Ethiopian Law 2 (1965) at 261-266.

${ }^{36}$ See, e.g., USAID Report, supra note 21, pp. 66 et seq.

${ }^{37}$ Arbitration is distinguished from ADR (alternative dispute resolution) mechanisms. In particular, arbitration - unlike such ADR mechanisms as mediation - results in the production of a legally binding award. Yet, there are some who regard arbitration as a form of ADR; see, e.g., Goode, R., Kronke, H. \& Mckendrick, E. (2007) Transnational Commercial Law: Text, Cases, and Materials. Oxford, OUP, at § 17-12 [hereinafter, Goode et al.]; Fekadu, supra note 18, pp. 105 et seq.

38 Satarkulova, I., (2006) "International Commercial Arbitration in the Kyrgyz Republic", Vindobona Journal of International Commercial Law \& Arbitration, 10, pp. 319-320; See also Redfern, A. et al. (2005) Law and Practice of International Commercial Arbitration. London, Sweet \& Maxwell, at § 1-51[hereinafter Redfern]; Garnett, R. et al. (2000) A Practical Guide to International Commercial Arbitration. New York, Oceana Publications, p. 14 [hereinafter Garnett].

${ }^{39}$ The choice of a neutral forum and tribunal matters a lot to at least one of the parties in international commercial dispute. Presumably, the home court of one party is not such a forum because the procedure, the language, and the lawyers are all alien to the other party; see Redfern, supra n. 38, at § 1-42. 
Improvements with respect to, for example, institutional arbitration are also indicative of the current trend toward a better utilisation of arbitration in commercial disputes. Two arbitral institutions - the Ethiopian Arbitration and Conciliation Centre (EACC) and the Arbitration Institute of the Addis Ababa Chamber of Commerce and Sectorial Associations (AACCSA) - have been established. ${ }^{40}$ These arbitral bodies primarily target at the business community as potential clients for their services. Moreover, as both institutions work under modern rules of arbitration and accept cases involving foreigners, ${ }^{41}$ they can eventually perhaps play a significant role as an alternative centre for commercial arbitration that involves transnational transactions as well. ${ }^{42}$

\section{Aspects of the Existing Arbitration Regime}

As noted above, the Ethiopian arbitration law is mainly based on the Civil Code and the CPC. While Title XX of the 1960 Civil Code contains the substantive rules on arbitration, the CPC carries rules of procedural importance. For our purpose, we may generally classify the rules as relating to (1) arbitration agreements, (2) the arbitral process, and (3) challenge and enforcement of arbitral awards.

\section{1- The Law on Arbitration Agreements}

The basis for arbitration, unlike litigation, is a contractual agreement between disputants. In the absence of an arbitration agreement, there would be no arbitration, except in situations where national laws prescribe mandatory arbitration. $^{43}$

${ }^{40}$ USAID Report, supra n. 21, p. 70; Tilahun, supra n. 17, p. 140; note, however, that the second of the two has recently suspended its arbitration activities.

${ }^{41}$ Ibid.; see also Re Ethiopian Privatisation Agency v Atilla Yildrim. In: EACC (2008) Report of Arbitral Awards, Vol.1.

${ }^{42}$ There has been dissatisfaction among Africans in general over the Eurocentricism of international commercial arbitration (see, e.g., Seznec, G. (2004), "The Role of African States in International Commercial Arbitration," Vindobona Journal of International Commercial Law \& Arbitration, 8, pp. 219-220; Assante, S. (1993), "The Perspective of African Countries on International Commercial Arbitration", Leiden Journal of International Law, 6, p. 350). Ethiopia cannot be an exception in this respect since numerous international arbitrations involving Ethiopian interests are often referred to institutions in Europe, often at the inconvenience of Ethiopian parties; see, e.g., The World Bank (2004) Ethiopia: Legal and Judicial Sector Assessment, p. 38.

${ }^{43}$ Under Ethiopian law, certain disputes are compulsorily arbitrable. For instance, a 1998 Proclamation on Cooperative Societies requires the compulsory submission of 
Though modern arbitration legislation refers to arbitration agreements generally, ${ }^{44}$ some national arbitration laws still distinguish between two forms of arbitration agreements, i.e., arbitral submission and arbitration clause. The dichotomy between arbitral submission and an arbitration clause is known in Ethiopia as well. ${ }^{45}$ While the former is understood as relating to existing disputes, the latter contemplates future disputes that might arise in the course of the performance of contractual obligations. ${ }^{46}$

Arbitration agreements usually deal with a range of issues including types of arbitration, seat of arbitration, choice of law, composition of arbitral tribunal, language of the arbitration, scope of the arbitration agreement, and the like. ${ }^{47}$ Also, arbitration agreements are normally subjected to statutes that prescribe substantive and formal requirements. Compliance with the statutory requirements is crucial, for the validity of the arbitration agreement may depend on it. ${ }^{48}$ Hence, due attention must be given to statutory requirements while drafting arbitration agreements.

Ethiopian law requires the fulfilment of certain substantive and formal requirements. The general substantive requirements relating to consent, capacity, and offer and acceptance are obviously relevant to arbitration

certain enumerated disputes to arbitration. See Art 49 of the Ethiopian Cooperatives Societies Proclamation No.147/1998.

${ }^{44}$ Sanders, P. (1999), Qui Vadis Arbitration? Sixty Years of Arbitration Practice, (The Hague, Kluwer Law International), p. 155 [hereinafter Sanders].

${ }^{45}$ Even though the English version of the Civil Code confusingly and consistently employs the term "arbitral submission" to generally refer to arbitration agreements, there are authorities that the English term "arbitral submission" is in fact a mistaken translation of the term "la convention d'arbitrage" from the initial French master text of the Civil Code. Besides, some articles in Chapter Two, Title XX of the Code expressly mention "arbitration clauses", hence, affirming the Civil Code's difference from its traditional civil law counterparts including the French Civil Code which used to deny enforcement to arbitration agreements over future disputes, i.e., arbitral clauses; see Bezzawork, p. 70; David, R. (1985) Arbitration in International Trade. Deventer, Kluwer Law Publishers, at §211[hereinafter David]; and Art 3328 of Civil Code.

${ }^{46}$ Redfern, supra n. 38, at § 3-02.

${ }^{47}$ Often, however, parties simply refer to institutional arbitration rules instead of including all these details in their arbitration contract.

${ }^{48}$ See, e.g., the decision of a Norwegian Court (cited in Redfern, supra n. 38, at § 3-09) that refused recognition to a foreign arbitral award due to the non-fulfilment of some formality requirements relating to the underlying arbitration agreement. 
agreements. $^{49}$ Apart from these substantive requirements, the test of "arbitrability" $" 50$ and the "capacity to arbitrate" $" 51$ need to be satisfied.

Formal requirements in arbitration agreements usually relate to the question of whether the agreement is oral or written. The universal rule requires commercial arbitration agreements and commercial transactions to be in writing. ${ }^{52}$ Though oral arbitration agreements are rare in international commercial transactions, ${ }^{53}$ some jurisdictions including Ethiopia ${ }^{54}$ are ready to recognise them. ${ }^{55}$

According to Art 3326 (2) of the Civil Code, arbitration agreements are required to be drawn in the form required by the law for disposing of the right to which the arbitration agreement relates. ${ }^{56}$ Applying the theory of Art 3326 (2) of the Civil Code, some arbitration agreements must, under the pain of nullity, be (1) written, (2) signed by the parties, and (3) attested by capable witnesses. For instance, an arbitration agreement with a certain administrative body ${ }^{57}$ need to be (1) in writing, ${ }^{58}$ (2) attested at least by two witnesses, ${ }^{59}$ and (3) registered with a court or notary. Understandably, such formality requirements are not good incentives to arbitral settlement of disputes involving administrative bodies.

Incidentally, written arbitration agreements which may be valid for the purpose of the UNCITRAL Model Law or the 1958 New York Convention may not necessarily be valid under Ethiopian law. As Ethiopian law requires written agreements to be attested by two witnesses under the pain of invalidity, arbitration agreements contained in telex or other means of communication

${ }^{49}$ Tilahun, supra n. 17, p. 119.

${ }^{50}$ See further discussions on the issue of arbitrability under section 4.1 infra.

${ }^{51}$ See, e.g., Ethiopian Mineral Development SC v JTT Trading, Federal Supreme Court, Cassation File No. 30727/2000.

${ }^{52}$ The 1958 New York Convention, which is widely adhered to, requires arbitration agreements to be in writing to support easy universal recognition and enforcement of the same. Also, the UNCITRAL Model law and numerous national arbitration laws prescribe this formality requirement; see, e.g., Sanders, pp.155-158.

${ }^{53}$ Bezzawork, supra n. 27, p. 77.

${ }^{54}$ The a contrario reading of Art 3326(2), Civil Code.

${ }^{55}$ Sanders, supra n. 44, pp. 155-158; Redfern, supra n. 38, at $\$ 1-09$.

${ }^{56}$ Art 3326 (2) of Civil Code: "the arbitration [agreement] shall be drawn in the form required by law for disposing without consideration of the right to which it relates."

${ }^{57}$ Art 1724 cum Art 3326 (2), Civil Code.

${ }^{58}$ The law, for instance, requires agreements involving the following transactions to be written: immovable properties, guarantee, insurance, and vessels; see Arts 1723, 1725(a), 1725(b), Civil Code, and Art 7, the 1960 Maritime Code of Ethiopia.

${ }^{59}$ According to Art 1727 (2) of Civil Code, written agreements are of no effect unless attested by two witnesses. 
which provide a record of the agreement are most likely to be invalid unless they relate to transactions which are not under the law required to be in writing. ${ }^{60}$

Overall, arbitration agreements fulfilling the above discussed substantive and formal requirements are generally enforceable. Non-performance of a valid and enforceable arbitration agreement by one party entitles the other to either demand performance or consider the arbitral agreement to have lapsed. ${ }^{61}$

\section{2- The Law Relating to Arbitral Process}

\subsection{1- Selection and Appointment}

Ethiopian law recognises the importance of the principles of party freedom and equality in the appointment of arbitrators. Parties are normally free not only in appointing arbitrators, but also in determining the identity, the number, the qualification, and jurisdiction of the same. ${ }^{62}$ And, any arbitration agreement must, under the pain of nullity, confer each party equal right regarding appointment of arbitrators. ${ }^{63}$

The procedure for the appointment of arbitrators usually commences when a party to an arbitration agreement specifies disputed issues and appoints the arbitrator(s). Subsequently, the other party to the arbitration agreement is given notice to exercise his right to appoint arbitrators. Parties, however, may abuse their right to appoint arbitrators by ignoring a call to appoint arbitrator(s) without delay. If the arbitration agreement contains detailed provisions regarding time limits within which the later party is bound to designate arbitrator(s), the matter is dealt with in accordance with the contractual provisions. Otherwise, the gap is usually filled by either institutional arbitration rules referred to in the contract or national laws that usually contain default rules.

The default rule in the Civil Code ${ }^{64}$ sets the time limit at thirty days - which begins to run from the day when notice is given to either the concerned party or to the person entrusted with the task of appointing arbitrators. After the expiry of the 30 day period, a court shall, upon request, appoint arbitrators. ${ }^{65}$

Another statutory default rule relates to the number of arbitrators. The Ethiopian default rule on the number of arbitrators is two. ${ }^{66}$ The Ethiopian Civil

${ }^{60}$ See, e.g., Bezzawork, supra n. 27, p. 77.

${ }^{61}$ Art 3344, Civil Code.

${ }^{62}$ Art 3331, Civil Code.

${ }^{63}$ Art 3335, Civil Code.

${ }^{64}$ Art 3334 (1), Civil Code.

${ }^{65}$ Ibid.

${ }^{66}$ Art 3331 (3), Civil Code. 
Code does not render an uneven number of arbitrators mandatory, and in effect, duly recognises the freedom of parties to opt for an even number of arbitrators. ${ }^{67}$ Statutory provisions dealing with cases where an even number of arbitrators fail to reach consensus on the award are, therefore, desirable. Accordingly, Art.3332, Civil Code, suggests the appointment of a presiding arbitrator where there is an even number of arbitrators. ${ }^{68}$

\subsection{2- Challenge and Disqualification}

The Civil Code contains rules entitling parties to challenge arbitrators. According to Art 3340, an arbitrator is disqualified, upon challenge by a party, where (a) there is doubt on the impartiality or independence of the arbitrator, (b) the arbitrator is not of age, sound mind or health, (c) he is unable to discharge his functions properly and within a reasonable time, (d) he is absent or convicted of a criminal offense. As a rule, a party cannot challenge an arbitrator chosen by him unless it is attributable to a reason arising subsequent to the appointment or for reasons he had knowledge of only after the appointment. ${ }^{69}$ An unsuccessful challenge for disqualification of an arbitrator is appealable to the court of law within ten days. ${ }^{70}$ This may at times be abused because the right of appeal may be used by parties to delay the proceedings on the merits. ${ }^{71}$

\subsection{3- Severability and Kompetenze-Kompetenze}

Often, the jurisdiction of arbitrators is defined in the arbitration agreement. Apart from the arbitration agreement, mandatory statutory provisions set limits on the competence of arbitrators. ${ }^{72}$ Currently, however, there are few limits on the power of arbitrators to rule on a range of issues, both preliminary and core. In particular, numerous jurisdictions allow arbitrators to rule on their jurisdiction, subject to judicial review only after an award on the merits has been rendered; hence the principle of Kompetenze-Kompetenze. ${ }^{73}$ This approach is

${ }^{67}$ Art 3331 (2), Civil Code.

${ }^{68}$ Art 3332, Civil Code. Note that some jurisdictions solved the problem by mandatorily requiring an uneven number of arbitrators or through the appointment of an umpire

(See Sanders, supra n. 44, pp. 232-233).

${ }^{69}$ Art 3341, Civil Code.

${ }^{70}$ Art 3342(3), Civil Code.

${ }^{71}$ Yet, there are some rules that remedy the downsides of the appeal right. See n. 127 infra and the accompanying text.

${ }^{72}$ Such limits take the form of, for example, legally inarbitrable matters.

${ }^{73}$ David, at $\S 309$; Redfern, supra n. 38 at $\$ 5-41$. 
widely praised for it saves arbitration proceedings from unnecessary delays due to "premature" court intervention. ${ }^{74}$

Apart from the principle of Kompetenze-Kompetenze, the principle of severability works in favour of a broad arbitral jurisdiction. Where recognised, the theory of separability allows arbitral tribunals to consider an arbitral clause based on which they assume jurisdiction - separable from the containing contract which is allegedly invalid. This, in turn, empowers arbitrators to decide on the validity or otherwise of the contract notwithstanding the fact that it is allegedly invalid. ${ }^{75}$ The principle is crucial in international commercial arbitrations which are more often based on arbitral clauses than arbitral submissions. $^{76}$

The two concepts are often interlinked, even sometimes confused. ${ }^{77} \mathrm{~A}$ complete Kompetenze-Kompetenze doctrine would, however, embrace the principle of separability. ${ }^{78}$

Ethiopian law recognises contractual freedom of parties - to an arbitration agreement - to authorise arbitrators to decide on disputes relating to their jurisdiction. ${ }^{79}$ Yet, the law provides two caveats. First, contractual provisions relating to the jurisdiction of the arbitrator shall be interpreted restrictively. ${ }^{80}$ Second, and most importantly, parties to an arbitration agreement may in no case authorise arbitrators to decide on the validity of the arbitration agreement. The second qualification apparently ousts arbitrators from jurisdiction regarding matters relating to the validity of arbitration agreement. Put in other words, the Ethiopian version of Kompetenze-Kompetenze is qualified by the doctrine of

${ }^{74}$ Gaillard, E. (2006) Reflections on the Use of Anti-Suit Injunctions in International Arbitration. In: Mistelis L. \& Lew J. eds. Pervasive Problems in International Arbitration. Alphen aan den Rijn, Kluwer Law International, at $\S 10-21$ [hereinafter Gaillard]; David, supra n. 45, at $\S 309$.

${ }^{75}$ However, the last word on the issue of validity would be given by courts who at a later stage may review the decision of the arbitrators on the matter.

${ }_{77}^{76}$ Redfern, supra n. 38, at § 3-02.

${ }_{77}^{77}$ David, supra n. 45, at $\S 209$; Redfern, supra n. 38, at $\S 5-42$.

78 Barceló, J. (2003) Who Decides the Arbitrators' Jurisdiction? Separability and Competence-Competence in Transnational Perspective, Vanderbilt Journal of Transnational Law, 36, p. 1122; Redfern, supra n. 38, at § 5-41-5-42; Tweeddale \& Tweeddale, supra n. 29, at§ 9-18.

${ }^{79}$ Art 3330 (2), Civil Code.

${ }^{80}$ Ibid, Art 3329. 
"inseparability" - which allows initial judicial scrutiny of issues regarding the validity of arbitration agreements. ${ }^{81}$

\subsection{4- Procedure before an Arbitral Tribunal}

The main rules governing the procedure of arbitration are contained in Art 317 of CPC. The first paragraph of Art 317 of CPC requires a degree of similarity between the procedure in arbitration and court proceedings. Mindful of the merits of avoiding any interpretation that would disturb the relative informality of the arbitral proceedings, scholars have long considered Art 317 as imposing a soft requirement of similarity designed only to ensure procedural fairness in arbitration. ${ }^{82}$ Elaborating on what particular similarity is required to exist between the procedure before an arbitration tribunal and a civil court, Art 317 (2) of CPC provides that arbitral procedure must at least be as fair as to enable parties to present their case and evidence.

\section{3- The Law Relating to Challenge and Enforcement of Arbitral Awards}

An arbitral award is legally required to be made "in the same form as a judgement." 83 Accordingly, an arbitral award must be in writing and signed by the arbitrators. ${ }^{84}$ The award must also contain the points for determination, the decisions thereon, and the reasons for such decisions. ${ }^{85}$ Where the award has been rendered by a majority decision, the minority must state in writing the decision which it thinks should be made together with the reasons thereof. ${ }^{86}$ The reading of Art 318 (2) cum. Art 182 (1), CPC, implies arbitrators must always give reasons irrespective of the parties' agreement that no reasons are to be given. ${ }^{87}$

Under Ethiopian law, parties to arbitration may appeal from awards. Art 351 of CPC provides a list of grounds based on which appeal from an award may lie. Conditions and grounds of appeal may also be laid down in the arbitration

${ }^{81}$ The UNCITRAL Model Law and numerous national laws on international arbitration recognise the jurisdiction of arbitrators to rule on their own jurisdiction, including any objections with respect to the existence and validity of the arbitration agreement.

${ }^{82}$ See, e.g., Sedler, R. (1968) Ethiopian Civil Procedure. Addis Ababa, Haile Selassie I University Press, p. 388 [hereinafter Sedler on Procedure].

${ }^{83}$ Art 318 (2), CPC.

${ }^{84}$ Ibid, Art 181(1) cum. Art 318(2).

${ }^{85}$ Id., Art 182(1).

${ }^{86}$ Id., Art 181(2).

${ }^{87}$ In contrast, the UNCITRAL Model Law allows parties to agree that no reasons are to be given in the award, in which case the arbitral award need not contain the reasons upon which it is based. 
agreement. ${ }^{88}$ Parties may either expand or exclude any basis of appeal from an arbitral award that would otherwise apply as a matter of law. ${ }^{89}$ It is to be noted, however, that Art 351 of CPC which, as a rule, allows broad judicial review of arbitral awards is unsuited to commercial arbitration with respect to which reduced judicial review is sought. ${ }^{90}$

Ethiopian law also recognises nullity actions ${ }^{91}$ as another means of recourse against arbitral awards. According to Art 356 of CPC, an award may be set aside where it is established that (1) the arbitrator decided matters not referred to him or made his award pursuant to a submission which was invalid or had lapsed; (2) the arbitrators, being two or more, did not act together; or (3) the arbitrator delegated any part of his authority whether to a stranger, to one of the parties, or to a co-arbitrator. ${ }^{92}$ Unlike agreements to exclude appeal from an award, an agreement to exclude a nullity action against an award is invalid. ${ }^{93}$

An award (other than foreign awards) that is tenable under Arts 351 and 356 of $\mathrm{CPC}^{94}$, may be executed without any prior condition in the same manner as an ordinary court judgement after application for homologation and execution of the award. ${ }^{95}$ Recognition and enforcement of foreign arbitral awards are governed by the rules contained in Art 461 of the Civil Code. Accordingly, a foreign arbitral award which passes the five tests relating to reciprocity, arbitrability, public policy, procedural fairness, and valid arbitration agreement would be enforced. However, a written application for the enforcement of a

${ }^{88}$ Art 350 (1), CPC.

${ }^{89}$ According to Art 350 (2), CPC, parties may waive their right of appeal. Yet, such waiver is of no effect unless made "with full knowledge of the circumstances". See further discussions on this point under section 4.3 infra.

${ }^{90}$ The philosophy of arbitrator autonomy and the "implicit realisation that arbitration is a unique method of dispute settlement which is a substitute for, rather than a part of, litigation" drive the present-day worldwide trend towards reduced judicial scrutiny of arbitral awards; see, e.g., Sanders, supra n. 44, pp. 318 et seq., Redfern, supra n. 38 at § 7-01 et seq., Garnett, supra n. 38, p. 113; and Evans, C. \& Ellis, R. (1973), "International Commercial Arbitration: a Comparison of Legal Regimes", Texas International Law Journal, 8, pp. 24-25 [hereinafter Evans \& Ellis].

${ }^{91}$ Note that a nullity action is the only legally available recourse against arbitral awards under the UNCITRAL Model Law and numerous modern national arbitration laws.

${ }^{92}$ Art 356, CPC.

${ }^{93}$ Art 355(1), CPC.

${ }^{94}$ An award remitted to arbitrators for reconsideration may also be enforced; see Art 354 (3), CPC.

${ }^{95}$ Art 319(2) cum. Art 461, CPC; international arbitral awards rendered by tribunals sited in Ethiopia are presumably enforced in the same manner. 
foreign arbitral award must be made to the Federal High Court. ${ }^{96}$ The Federal High Court then gives opportunity to the party against whom enforcement is sought to present his observations within such time as it discretionarily fixes. ${ }^{97}$ No hearing is conducted unless the court for some special reason to be recorded decides to hear the parties. ${ }^{98}$ Normally, the court allows or refuses to allow execution on the basis of the application unless it decides pleadings are to be submitted. If the application is allowed, "the foreign award is executed in Ethiopia as though it had been rendered in Ethiopia." 99 The characterisation as Ethiopian of foreign awards is crucial, for it accords the foreign arbitral award res judicata status. ${ }^{100}$

\section{The Role of Ethiopian Courts in Commercial Arbitration}

The involvement of national courts is crucial to the overall efficacy of arbitration, both domestic and international. Instances calling for court intervention may appear at all stages of the arbitral proceedings. Yet, there is a need to maintain a balance between the levels of court involvement and the smooth functioning of arbitration - which is a contractual alternative to judicial dispute settlement. In this section, we discuss the role of Ethiopian courts during the three stages of arbitral proceeding, i.e., before the commencement of the proceeding, during, the proceeding and after the rendition.

\section{1- Before and at the Beginning of the Arbitration Proceeding}

One of the issues that may initially call for court intervention is related to the enforcement of the arbitration agreement. It is the task of courts, not arbitrators, to enforce the arbitration agreement should one of the parties (1) bring an arbitrable dispute to a court of law or (2) refuse to perform the acts required for setting the arbitration in motion. ${ }^{101}$

Where a party insists on arbitration, Ethiopian courts have practically declined to assume jurisdiction on the merits and, accordingly, referred disputes to arbitration. This judicial practice has a long history dating at least as far back

${ }^{96}$ Read cumulatively Art 11(2) (c), Federal Courts Proclamation, Proclamation No. 25/1996 and Arts 456-457, CPC. According to Art 457, CPC, the application must be accompanied by (1) a certified copy of the award to be executed; and (2) a certificate signed by the arbitrator or the registrar of the institution [in case of institutional arbitration] to the effect that the award is final and enforceable.

${ }^{97}$ Ibid, Art 459.

${ }^{98}$ Id., Art 461 (1).

${ }^{99}$ Id., Art 460 (3).

${ }^{100}$ Id., Art 461 (2) cum. Art 460 (3) cum. Art 5.

${ }^{101}$ Art 3344 (1), Civil Code. 
as the early 1960s. In Highway Authority v Solel Boneh Ltd, ${ }^{102}$ the then Supreme Imperial Court of Ethiopia affirmed the decision of the High Court ordering the government agency to comply with a clause of its contract with Solel Boneh Ltd that provided for submission of all disputes under the contract to arbitration. In a similar case involving a government agency, ${ }^{103}$ the Federal Supreme Court of Ethiopia denied a motion by the appellant government agency against enforcement of an arbitration agreement.

Numerous cases related to the enforcement of arbitration agreements involve government agencies. This is particularly because government agencies - the most notable Ethiopian participants in international commercial arbitrations often try to take advantage of the unsettled Ethiopian law on arbitrability of administrative contracts. In Highway Authority v Solel Boneh Ltd, for example, the Imperial Highway Authority argued that Art 3194(1) of the Civil Code, which provides "the court may not order the administrative authorities to perform their obligation," sets a limit on the enforceability of arbitration agreements regarding administrative contracts. The Court, however, ruled against the Authority. In so doing, the Court reasoned that Art 3194 (1) of the Civil Code does not exonerate a government agency from referring to an arbitrator since this particular provision is qualified by other supplementary provisions contained in the same Code. ${ }^{104}$

The holding of the Court, however, faced serious challenge upon the enactment of CPC, whose Art 315 (2) reads "no arbitration may take place in relation to administrative contracts ... or in any case where it is prohibited by law." 105 Government agencies are now provided with an alternative statutory provision to avoid arbitration of disputes. And, this provision has successfully been invoked by government agencies to challenge enforcement of arbitration agreements and awards. For instance, the High Court of Addis Ababa ${ }^{106}$ rejected enforcement to an international arbitral award against an Ethiopian administrative agency.

\footnotetext{
${ }^{102}$ See n.35 supra.

${ }^{103}$ Water Resource Ministry v Siyoum \& Ambaye General Contractors, Federal Supreme Court, Civil Appeal Case No.19659/1997.

${ }^{104}$ In particular, the court mentioned the Code's provisions on administrative contracts are incomplete and as such supplemented by other provisions of the Code including those on arbitral submission of disputes, i.e., Art 3325-3346, which do not expressly limit arbitral submission of matters regarding administrative contract.

${ }^{105}$ Note that the decision of the Court in Highway Authority $v$ Solel Boneh Ltd came only before the enactment of CPC in 1965.

106 Water Supply and Sewage Authority v. Kundan Singh Construction Limited, Addis Ababa High Court, Civil File No. 688/79.
} 
Apparently, Art 315 of the CPC is explicit in stating the inarbitrability of administrative contracts. However, this has not dissuaded some from invoking the same provision, and in particular paragraph four reads "nothing in this chapter [Arts 315-319 of CPC] shall affect the provisions of Arts 3325-3346 of the Civil Code." The text of Arts 3325-3346 of the Civil Code - which accordingly overrides the provisions of Art 315 (2) - is silent as to whether disputes involving administrative contracts are arbitrable or not. This statutory silence has been taken by some ${ }^{107}$ as indicative of arbitrability, as opposed to inarbitrability, of administrative contracts.

In Water Supply and Sewage Authority v. Kundan Singh Construction Limited, the High Court of Addis Ababa, however, rejected the argument of the Indian party that "Art 315 (2) of CPC should not be given effect since the overriding substantive law is silent as to the inarbitrability of issues arising out of administrative contracts." The court's decision has been seen by some commentators as an unconvincing attempt to "get around the strong point" under Art 315 (4) of CPC. ${ }^{108}$

The controversy regarding the arbitrability of administrative contracts survived the $20^{\text {th }}$ century. In Water Resource Ministry v. Siyoum \& Ambaye General Contractors, ${ }^{109}$ the government agency argued the contract in which the arbitral clause was contained was an administrative one, in respect of which arbitration was prohibited by law. In deciding the matter, the court went on to define, in light of the principles of Ethiopian administrative contract law, which contracts are administrative and which are not. Eventually, it adopted a narrow definition of administrative contracts which resulted in the exclusion of the contract at issue from what might constitute an administrative contract for the purpose of Ethiopian law. Then the court concluded:

"The appellant's argument that the matter should not be referred to arbitration is based on the theory that the matter, though contractually arbitrable, is inarbitrable in law as it relates to an administrative contract. But, the referred contract does not qualify as administrative one in respect of which Art 315 (2) of CPC prohibits arbitration. Accordingly, disputes arising out of it may be referred to arbitration pursuant to the contractual stipulation." 110

The case is an instance of apparent judicial approval of the view that matters of administrative contract are inarbitrable under Ethiopian law.

${ }^{107}$ Bezzawork supra note 27, p. 85; Zekarias, Keneaa (1994) "Arbitrability in Ethiopia: Posing the Problem" Journal of Ethiopian Law, 17, p. 120 [hereinafter Zekarias].

${ }^{108}$ Zekarias, ibid, p. 120.

109 See supra n. 103

${ }^{110}$ Translation mine. 
Nonetheless, in Zemzem PLC v Illubabor Zone Education Department, ${ }^{111}$ the Federal Supreme Court's Cassation Division appeared to unsettle the above interpretation. ${ }^{12}$ The issue involved the interpretation of Art 24 of the contract entered into between the disputants. This article provided for the arbitral submission of disputes involving the parties with, of course, the possible alternative of judicial settlement of the same. The provision interpreted by the lower courts as warranting judicial settlement of the dispute as the concerned contractual provision had not excluded, but rather contemplated, litigation. The Federal Supreme Court's Cassation division, however, interpreted the contractual provisions as only allowing arbitration, not litigation. Unlike in many of the cases cited above, the government agency did not invoke Art 315 of CPC which apparently exonerates it from arbitration. Nonetheless, the Cassation Bench should have dealt with it notwithstanding the failure of the Zone Education Department to invoke Art 315 (2) since arbitrability or otherwise of the dispute at issue is a public policy one. ${ }^{113}$ The failure of the Court to specifically deal with the issue coupled with the final ruling which compelled an administrative agency to arbitration led to a remark that the Bench's holding as "hammering the final nail on Art 315(2)'s coffin" thereby heralding the enforceability of arbitration agreements over administrative contract matters. The ruling of the Cassation Bench seems to reinforce the dominant academic view $^{114}$ that matters relating to administrative contracts are arbitrable. However, I think it is too early to conclude that that Zemzem PLC v Illubabor Zone Education Department settles the status of the controversial Art 315 (2) of the Civil Procedure Code as the Cassation Bench has not directly addressed the issue. $^{115}$

The enforceability of procedural agreements by the parties is unclear. The $a$ contrario reading of Art 317(2) of CPC indicates that parties are free to agree over procedural matters. ${ }^{116}$ In particular, they may exempt arbitrators from

111 Zemzem PLC v Illubabor Zone Education Department, Federal Supreme Court, Cassation File No.16896/ 1998.

112 For more on this, see Tecle Hagos (2009), "Adjudication and Arbitrability of Government Construction Contracts", Mizan Law Review 3(1), pp. 1-32 [hereinafter Tecle].

${ }^{113}$ Ibid, p. 24.

114 Tilahun, supra n. 17, at 126; Zakarias, supra n. 107, at 120 et seq.; Bezzawork, supra n. 27, at 83 et seq.

115 Tecle, supra n. 112, who holds a different view also concedes the decision of the Bench does not finally settle some issues regarding arbitrability of administrative contracts; see Tecle, pp. 24-26.

116 Perhaps, this article may allow arbitration by way of composition, i.e., amiable compositeur. See, however, Bezzawork, supra n. 27 (at 80) who argues that the 
complying with the statutory rules relating to hearing and taking of evidence. However, Art 351 of the same Code, which lists procedural irregularities as a ground for challenging arbitral awards, casts doubt on the unqualified enforceability of some procedural agreements. Moreover, it is argued the Amharic version of Art 3325(1) of the Civil Code, which appears to generally require arbitration to be conducted "in accordance with the law," qualifies the provisions of Art 317 (2) of $\mathrm{CPC}^{117}$. The simultaneous existence of all these statutory provisions makes the intention of the legislator vis-à-vis the autonomy of parties to agree on procedural matters unclear. On the one hand, the law appears to allow parties to even agree over the inapplicability of the statutory rules on fair hearing. On the other, irregularities in the arbitral proceedings which may, for example, result from the inapplicability of the statutory rules on fair hearing - can be invoked as valid grounds for challenging arbitral awards. However, it may be fair to argue that Ethiopian law allows parties to agree over procedural matters subject to the provisions of Art 351 of CPC and Art 3325 of the Civil Code. Accordingly, it seems likely that Ethiopian courts would be unsympathetic toward procedural agreements that aim to do away with statutory rules on fair hearing.

Apart from enforcing valid arbitration agreements, appointing members of the arbitral tribunals is another area where courts may participate during an early stage of arbitration. ${ }^{118}$ As per Art 3344(1) of the Civil Code, a party to arbitration agreement may demand judicial enforcement of the arbitration agreement if the other party refuses to perform the acts required for setting the arbitration in motion (e.g. appointing arbitrators). And, courts who are called upon to enforce arbitration agreement may appoint arbitrators on behalf of the defaulting party. The scope of the power of the court called to appoint an

stipulation under Art 317 (2) of CPC is qualified by the substantive law on arbitration, particularly Art 3325 (1) of Civil Code.

${ }_{117}^{11}$ Bezzawork, supra n. 27, p. 80.

11 Art 3334(1) cum. Art 3343, Civil Code; for more on this, see Zakarias, Keneaa (2007) "Formation of Arbitral Tribunals and Disqualification and Removal of Arbitrators under Ethiopian Law", Journal of Ethiopian Law, 21, pp.143-145. 
arbitrator is however unclear. Put in other words, it is imprecise ${ }^{119}$ whether the function of courts in appointing arbitrators is administrative. ${ }^{120}$

In practice, the role of Ethiopian courts in appointing arbitrator appears to be a judicial one. For instance, in Ethiopian Mineral Development SC v JTT Trading, ${ }^{121}$ where a party to an arbitration agreement approached the Federal First Instance Court to appoint arbitrators on behalf of the other party which allegedly failed to perform its contractual obligation to appoint arbitrators, the Court reviewed the validity of the arbitration agreement. Although the court finally found that the arbitration agreement was valid, it did not appoint arbitrators on behalf of the defaulting party; rather it simply ordered the party to appoint its own arbitrators. ${ }^{122}$ Moreover, appeals from the decision of the court culminated in the Federal Cassation Bench which held that the arbitration agreement is invalid and hence unenforceable. ${ }^{123}$

This practice is not ideal for commercial arbitration in general and international commercial arbitration in particular. Even though the role and power of the court in appointing arbitrators is the subject of disagreement elsewhere, ${ }^{124}$ the prevailing view with regard to international arbitration is that judicial appointment of arbitrators is merely an administrative function which

${ }^{119}$ Art 3334(1) of Civil Code, as per which courts intervene to appoint arbitrators, reads: "Where the other party or the person required to appoint an arbitrator fails to do so within thirty days, the court shall appoint such arbitrator." Though one would tempt to argue that the provision limits the role of courts to only appointing arbitrators, the article does not expressly prohibit courts from verifying - which they in fact do - the underlying arbitration agreement.

${ }^{120}$ If it is an administrative one, courts do nothing but appoint arbitrators without any judicial review of the validity of arbitration agreement. In contrast, if it is a judicial one, courts may review the validity of the arbitration agreement before they appoint arbitrators.

121 Ethiopian Minerals Development SC v JTT Trading, Federal Cassation Chilot, Cassation File No. 30727 [Ginbot 19, 2000 EC].

${ }^{122}$ Note however that the court had the power and in fact the duty to appoint arbitrators in such cases; see Art 3334 (1), Civil Code.

${ }^{123}$ For a critique of the decision of the Federal Cassation Bench, see Hailegabriel, Gedecho (2010), Managers' Power, Ultra vires and Third Parties under Ethiopian Law: a Critique of Ethiopian Mineral Development SC v JTT Trading," Bahir Dar University Journal of Law, 1(2) [forthcoming].

${ }^{124}$ See, e.g., Sen, A. (2000) "The Role of Courts in the Appointment of Arbitrators -an Analysis with Reference to the Supreme Court of India's Decision in S.B.P. v Patel Engineering", Vindobona Journal of International Commercial Law and Arbitration, 10, p. 46 [hereinafter Sen]. 
does not require the exercise of judicial power by courts. ${ }^{125}$ It is commendable if Ethiopian courts decline jurisdiction to incidentally determine the validity of arbitration agreements when they are called to appoint arbitrators. ${ }^{126}$

Ethiopian courts may also decide over preliminary challenges to arbitration, e.g., application for the disqualification of appointed arbitrators. Under Ethiopian law, an unsuccessful challenge for disqualification of an arbitrator is appealable to the court of law within ten days. ${ }^{127}$ Though the ten-day period seems to lessen the adverse effects of the appeal right, it does not rule out the possible utility of the appeal right to delay proceedings on the merits. The undesirability of the application of this rule to cases of international commercial arbitration - where dilatory intervention by national courts is worth avoiding, has long been recognised. ${ }^{128}$ As one writer notes:

"The party making the challenge should bear a heavy burden of proof, and challenges should not be sustained merely to avoid controversy, lest they be used for ad terrorem effect. Once decided within the arbitral regime the matter should be final and not subject to interlocutory judicial review. Even after the award has been rendered the challenge should not be subject to further litigation in a reviewing court, unless it can be shown that the direct result of the decision rejecting the challenge was a seriously tainted award." ${ }^{129}$ [Emphasis added].

Moreover, Art 3342 (3) of the Civil Code allows judicial review of application for disqualification. CPC provisions on appeal from and setting aside of arbitral awards may apparently serve a similar purpose, albeit at a later stage.

${ }^{125} \mathrm{Ibid}, 52$; note also that the trend elsewhere is to reduce judicial intervention in the earlier stage of arbitration. Thus, the principle of competence-competence empowers arbitrators to assume jurisdiction over jurisdictional matters including those related to the existence and validity of the arbitration agreement.

126 Nonetheless, a marginal review of the arbitration agreement before appointing arbitrators is necessary to save parties from future costs related to arbitration under invalid arbitration agreements. Besides, Ethiopian law reserves the power to rule over the validity or otherwise of arbitration agreement to courts (see discussions under 4.2). Yet, it is submitted that this can expediently be done at a later stage, e.g., during appeal and setting aside procedures, so that premature judicial intervention will be reduced.

${ }^{127}$ Art 3342 (3), Civil Code.

${ }^{128}$ David, supra n. 45 , at $\S 287$; for a detailed analysis on the role of courts and current trends thereto, see Redfern, supra n. 38, Chapter 7.

129 Tupman, W. (1989) "Challenge and Disqualification of Arbitrators in International Commercial Arbitration", The International and Comparative Law Quarterly, 38, p. 52 [hereinafter Tupman]. 
In a fairly recent case, ${ }^{130}$ the Federal Supreme Court denied an appeal from an unsuccessful challenge for disqualification as the appeal was brought only after an award by the challenged arbitrator was rendered. The Court's ruling looks consistent with the spirit of Art 3342(1) of the Civil Code, which requires application for disqualification to be made before the giving of the award and as soon as the challenging party knew of the grounds for disqualification. ${ }^{131}$

A scenario that needs to be taken note of is a situation where a challenge, rejected by an arbitral tribunal, is appealed to a court. The issue that arises would be whether arbitrators, perhaps including the challenged arbitrator, can proceed with the arbitration process pending final court decision on the matter? Literature reveals the answer is not the same everywhere. In some jurisdictions, arbitrators are not bound to suspend the proceeding, whilst numerous countries oblige arbitrators to suspend hearing until the court has the last word on the application for disqualification. ${ }^{132}$ René David underlines the merits of the former approach, especially where cases of international arbitration are involved. ${ }^{133}$ Albeit risky, ${ }^{134}$ allowing the continuation of the arbitral proceeding by postponing any judicial review to only after an award has been made is recommended. ${ }^{135}$

Interlocutory judicial review of an application for disqualification is legally possible in Ethiopia. ${ }^{136}$ Nonetheless, there is no clear legal authority for a court to suspend the arbitration proceeding until its final decision on the matter. ${ }^{137}$

${ }^{130}$ Siemens PLC v Berta Construction PLC, Federal Supreme Court, Civil Appeal File No.12648/96.

${ }^{131}$ Under Ethiopian law, challenge can be brought as late as any time before the giving of the award. Yet, late challenges should be based on grounds that have only recently come to the attention of the party; see Art 3342(1), Civil Code.

${ }^{132}$ David, supra n. 45 , at $\S 287$.

${ }^{133}$ Ibid.

134 The independence of arbitration from "premature" court intervention does not always guarantee efficiency. Although saving the arbitral process from early judicial intervention contributes to the prompt settlement of disputes, it is sometimes neither cost- nor time-effective for at least the party dragged to the arbitration. Yet, it is now widely believed that the downside of the independence (from premature judicial intervention) of arbitration would be lessened by such procedures as setting aside; see, e.g., Tupman.

${ }^{135}$ David, supra n. 45, at $\S 287$.

${ }^{136}$ For more on this, see discussions in 3.2 infra".

137 Yet, one would possibly argue courts do have the inherent power to order the suspension of arbitral proceedings whenever they think appropriate. Even more, the power of courts to order provisional remedies including temporary injunctions may used to justify judicial intervention at the preliminary stage of arbitration; see, e.g., 
Practically, however, Ethiopian courts have ordered the suspension of an arbitral proceeding pending judicial review of an application for disqualification. ${ }^{138}$ Such suspension orders - widely known as "anti-arbitration injunctions" - have been rebuffed by the concerned arbitrators ${ }^{139}$ and some scholars. ${ }^{140}$

Generally, Ethiopian courts play a positive role in enforcing valid arbitration agreements. Yet, their role in setting precedent over the controversial matter regarding arbitrability of administrative contractual matters has been elusive. Moreover, the much looked-for judicial restraint regarding interlocutory matters like challenges to jurisdiction is absent in Ethiopia.

\section{2- During the Arbitration}

Arbitration is a method of dispute settlement which is alternative to, not part of, court litigation. ${ }^{141}$ It is widely held that court intervention, especially during the proceeding of the arbitration, is undesirable as it may frustrate and disrupt this alternative dispute settlement process. ${ }^{142}$ Many jurisdictions have thus (1) relegated the role of courts, during this stage, to that of a supportive one ${ }^{143}$ and (2) recognised the procedural autonomy of parties and their arbitrators. ${ }^{144}$ Arbitrators are accordingly empowered to, for example, award preliminary interim measures and relief, including interim relief in respect of parallel proceedings; and they are not under obligation to seek the assistance of the courts. $^{145}$

Art 155-156, CPC. Note also that the CPC's provisions on stay of proceedings might be of relevance.

138 Salini Costruttori Spa v the Federal Democratic Republic of Ethiopia, Addis Ababa Water \& Sewage Authority, ICC Arbitration Case No.10623/AER/ACS (2001) [hereinafter Salini].

139 Ibid, § 125-178; more on the case will follow in the next section.

${ }^{140}$ See, e.g., Bachand, F. (2005), "Must an ICC Arbitral Tribunal Comply with an Antisuit Injunction Issued by the Courts of the Seat of Arbitration?", Mealey's International Arbitration Review 20(3), pp. 47 et seq.[hereinafter Bachand]; Gaillard, supra n. 74, at $\S 10-21$; Scherer, M. \& Giovannini, T. (2005), "AntiArbitration and Anti-Suit Injunctions in International Arbitration: Some Remarks Following a Recent Judgement of the Geneva Court," Stockholm International Arbitration Review, 3, pp. 209-211[hereinafter Scherer \& Giovannini].

${ }^{141}$ Evans \& Ellis, supra n. 90, p. 24.

${ }^{142}$ Ibid.; Redfern, supra n. 38, at $§ 7-10$.

${ }^{143}$ Ibid.

${ }^{144}$ Petrochilos, G. (2004) Procedural Law in International Arbitration. Oxford, OUP, at §3-73 et seq. [hereinafter Petrochilos].

${ }^{145}$ Sanders, supra n. 44, at 271 et seq.; Tweeddale \& Tweeddale, supra n. 29, at § 9-12 $-9-87$. 
The autonomy of commercial arbitration from national court supervision is not, however, absolute even in Model Law countries where mandatory rules on independence and impartiality of arbitrators and party equality enjoy a complete free rein. ${ }^{146}$ Accordingly, the competence of courts, for instance, to entertain challenges to arbitrators' jurisdiction before any award has been issued is recognised. ${ }^{147}$ This is particularly important to address the concerns of parties, who should not be forced to go through the whole process of arbitration which may be deemed a nullity afterwards. ${ }^{148}$

Pending the arbitral proceeding, the autonomy of arbitration does not preclude a party to an arbitration agreement from applying to the court in order to preserve his rights. The right of parties to apply to the court for assistance is imperative as arbitrators lack actual power - though not legal power - to compel parties to, for example, arbitrate and give evidence. ${ }^{149}$ For instance, court-issued summons are needed subsequent to a witness's failure to appear in answer to the summons issued by an arbitral tribunal. ${ }^{150}$

Ethiopian law allows a fair degree of arbitral autonomy. It, for instance, empowers arbitrators to initially decide on their jurisdiction, ${ }^{151}$ to grant orders in relation to interim measures of protection and measures relating to the attendance of witnesses, etc. ${ }^{152}$ Arbitrators are the masters of their own procedure as long as they guarantee procedural fairness. ${ }^{153}$ Arguably, they can

${ }^{146}$ Petrochilos, supra n. 144, at § 3-78; Art 18-19, UNCITRAL Model Law.

${ }^{147}$ Redfern, supra n. 38, at § 5-47; Art 16, UNCITRAL Model Law.

${ }^{148}$ Petrochilos, supra n. 144, at $\S 4-65$; but see, Redfern, at $\S 5-47$.

149 In some jurisdictions, arbitrators rely on the principle of adverse inference to sanction compliance with their interim orders; see Tweeddale \& Tweeddale, at $\S 9$ 967.

${ }^{150}$ Art 317(3), CPC.

${ }^{151}$ Art 3330(1)-(2), Civil Code. As seen earlier, however, this principle seems to be limited by a substantive rule contained in Art 3330(3). This provision expressly prohibits parties from authorising arbitrators to decide on the validity or otherwise of an arbitration agreement. It is thus the power of courts, not arbitrators, to decide on the [in]validity of arbitration agreements. See n. 81 supra and the accompanying text.

152 The absence of express statutory provisions prohibiting arbitral tribunals from awarding preliminary or interim reliefs coupled with some inference from such provisions as Art 317(3) of CPC reflect the legislative policy of permitting arbitrators to award preliminary or interim reliefs. See also Tilahun, p. 137.

${ }^{153}$ Procedural unfairness results in the annulment/setting aside or judicial review of the award afterwards; see Art 351 and Art 356, CPC; also Re Gebrehiwet Debesai v Fondiaria Fire Insurance Co., Supreme Imperial Court, Civil Appeal No.134/56[reported in Journal of Ethiopian Law, 2(2), pp. 267-275]. 
be flexible in the realm of procedural fairness if they are authorised to do so by the parties, ${ }^{154}$ subject to the duty to respect the fundamental principle of equality of the parties.

Ethiopian law also recognises the importance of the right of parties to arbitration to apply for court assistance whenever appropriate. ${ }^{155}$ Such applications will neither be considered a breach of agreement to arbitrate nor a waiver of the agreement to arbitrate. ${ }^{156}$

Parties to an arbitration agreement approach courts, inter alia, seeking interim relief enjoining a pending arbitral proceeding. One of the pervasive problems in commercial arbitral proceedings relates to such relief which, when granted, potentially disrupts the arbitral proceeding. While courts in developed arbitral jurisdictions cautiously exercise self-restraint towards applications for relief enjoining a pending arbitration, i.e., anti-arbitration injunctions, ${ }^{157}$ a comparable caution is reportedly lacking in some jurisdictions like Ethiopia.

It has been reported ${ }^{158}$ that Ethiopian Federal Supreme Court accepted a party's application to restrain an international arbitration proceeding pending court decision on a preliminary objection to the jurisdiction of the arbitrators. The application was brought based on Art 3342 (3) of the Civil Code which allows appeal against an application for disqualification turned down by the arbitrators. Though there is no express legal authority - within the pertinent provisions of the Civil Code and CPC - for courts to suspend the arbitration until they finally give a decision on the pending application for disqualification, Ethiopian courts have practically done so with the help of the CPC's provisions on temporary injunctions and stay of proceedings. ${ }^{159}$ Such court injunctions, which unduly interfere with the arbitral process, have widely been dismissed as incompatible with the universally recognised principle of competencecompetence and the overall efficacy of arbitral settlement of disputes. ${ }^{160}$ More frequently, arbitral tribunals against whom anti-arbitration injunctions were issued by courts in the seat ${ }^{161}$ state refuse to suspend the arbitration. ${ }^{162}$

${ }^{154}$ The phrase "unless by the submission it has been exempted from doing so" in Art 317(2) of CPC warrant such an argument.

${ }_{155}^{155}$ Art 317(3), CPC; Art 3344(2), Civil Code.

${ }^{156}$ Ibid.

${ }^{157}$ Redfern, supra n. 38, at $\S 7-33$ et seq.; Gaillard, supra n. 74, at $\S 10-15$ - 10-16.

${ }^{158}$ Salini, supra n. $138, \S 75$ et seq.

${ }^{159}$ Ibid., $\$ 76$ and 121 .

${ }^{160} I d ., \S 177$; See Gaillard, at $\S 10-21$; Scherer \& Giovannini, supra n. 140, p. 218.

${ }^{161}$ Seat is the place where arbitral proceedings are undertaken. Note that in almost all cases, the seat is the place designated as such by the parties. As a matter of practice, however, arbitral proceedings may actually be held outside the designated seat. For 
In Salini, ${ }^{163}$ the ICC Arbitral Tribunal, which was ordered by the Federal Supreme Court to suspend the arbitration pending judicial decision on the qualification/jurisdiction of the arbitrators, declined to do so. The tribunal reasoned its decision on (1) purported duties it owed to the parties in the arbitration, (2) its duty to make every effort to render an enforceable award, and (3) a theory that a state or state entity cannot resort to the state's courts to frustrate an arbitration agreement. ${ }^{164}$ The tribunal particularly held that "its duty to the parties," which according to it "derived from the arbitration agreement must be followed even if that requires non-compliance with a court order."165

Many arbitration practitioners and scholars seem to sympathise with the findings, or at least the merits, of the arbitration tribunal. ${ }^{166}$ Yet, there are some who argue that injunctions issued by Ethiopian courts, which in the case at hand assume supervisory jurisdiction, must be honoured. ${ }^{167}$ Though unmoved by the argument of the ICC Tribunal that "it must follow its own judgment, even if that requires non-compliance with orders from the supervisory court", ${ }^{168}$ it is regrettable that Ethiopian courts went so far in undesirably and, of course, unsuccessfully $^{169}$ challenging (1) the principle of competence-competence,

instance, some arbitral proceedings wherein Ethiopia is the seat may in fact be undertaken in France. For more on this, see Rubino-Sammartano, M. (1999) International Arbitration: Law and Practice. $2^{\text {nd }}$ ed. The Hague, Kluwer Law International, pp. 563-570; Redfern, supra n. 38, at § 2-14-15.

162 See, e.g., Himpurna California Energy Ltd v Republic of Indonesia [reported in Yearbook Commercial Arbitration. (2000) Vol. XXV, pp. 186-215; Mealey's International Arbitration Report (2000) 15(1), pp. A-i].

${ }^{163}$ See n.138 supra.

${ }^{164}$ Salini, supra n. $138, \S 125-178$.

${ }^{165}$ Ibid., $\$ 142$.

${ }^{166}$ E.g., Gaillard, supra n. 74, at $\S 10-21$; Bachand, supra n. 140, at 47; Scherer M. \& Giovannini, supra n. 140, at 218.

${ }^{167}$ E.g., Mohtashami, R. (2005), "In Defense of Injunctions Issued by the Court's of the Place of Arbitration: A Brief Reply to Professor Bachand's Commentary on Salini Costruttori S.p.a. v. Ethiopia”, Mealey's International Arbitration Review, (20)5, p. 44; Partasides, C. (2004), "Solutions offered by Transnational Rules in Case of Interference by the courts of the place of arbitration", Transnational Dispute Management, 1(2), pp. 8 et seq. [hereinafter Partasides].

168 I sympathise with the argument of Partasides that (1) enforcing the arbitration agreement must also involve recognising the supervisory jurisdiction chosen by the parties and (2) that the fact that one of the parties to an arbitration agreement is a state agency of country $\mathrm{X}$ does not vacate, or invalidate, the parties' agreement that the courts of country X have supervisory jurisdiction.

169 The suspension order by the Ethiopian court was not actually successful in vacating the arbitrator from jurisdiction; the arbitrators rather defied the court order and 
which is arguably ${ }^{170}$ incorporated under the national arbitration law and (2) the efficient utilisation of arbitration.

\section{3- After the Arbitration: Setting Aside, Appeal, and Enforcement of Awards}

To a varying degree, the role of courts in controlling the outcomes of arbitration - international or domestic - is universally recognised. ${ }^{171}$ Two important functions are undertaken by courts during this stage: entertaining challenges to arbitral awards and applications for enforcement of the same.

\subsection{1- Challenging Arbitral Awards}

Appeal is one way of challenging arbitral awards under Ethiopian law. Four general grounds of appeal are listed in Art 351 of CPC. Accordingly, appeal is allowed where:

(1) the award is inconsistent, uncertain or ambiguous or is on its face wrong in matter of law or fact;

(2) the arbitrator omitted to decide matters referred to him;

(3) irregularities ${ }^{172}$ have occurred in the proceedings; or

(4) the arbitrator has been guilty of misconduct. ${ }^{173}$

Additional conditions and grounds of appeal may also be laid down contractually. As a result, broad judicial review of arbitral awards is possible. However, Sedler in his Ethiopian Civil Procedure posits "an award is not subject to review [to] the same extent as a judgement". ${ }^{174}$ For him:

"the decision of the arbitrator on [a] question of law or fact is not reviewable as such. It is only where the decision is patently incorrect, e.g., where he

continued the proceeding which resulted in an award that may perhaps have a limited chance of enforcement in the seat state; see Redfern, supra n. 38, at § 7-37.

${ }^{170}$ See n.79-81 supra and the accompanying texts.

${ }^{171}$ Redfern, supra n. 38, at $§ 7-41$.

${ }^{172}$ Such irregularities include (1) failure to inform the parties or one of them of the time or place of the hearing or to comply with the terms of the submission regarding admissibility of evidence; or (2) refusal to hear the evidence of material witness or taking evidence in the absence of the parties or one of them (See Art 351(c) (i) - (ii), CPC). Note, however, that this provision is not compatible with Art 317 (2) of the same Code which apparently recognises parties' right to exempt arbitrators from complying with some procedural matters.

173 According to an illustrative list under Art 351(d), misconduct of arbitrator include situations where the arbitrator (a) heard one of the parties not the other, (b) is unduly influenced by one of the parties, whether by bribes or otherwise, or (c) acquired an interest in the subject matter of dispute referred to him.

${ }^{174}$ Sedler on Procedure, supra n. 82, p. 390. 
enforced an oral contract, which the law requires to be in writing that is subject to review... Irregularities or misconduct by the arbitrator justify review only where they are such as to prevent a fair hearing or demonstrate that the arbitrator did not render an unbiased judgment ... it is important to remember that an arbitral award may not be reviewed on the same ground as a judgement." 175

Sedler's view that arbitral awards may not be reviewed as widely as judgements is consistent with the jurisprudence elsewhere. ${ }^{176}$ Yet, the practice in Ethiopian courts does not support such a view. Inconsistent with what Sedler holds, courts have shown their willingness in practice to review awards on the merits when they are appealed. ${ }^{177}$ Moreover, courts do not have difficulties in proceeding to review the merits of arbitral awards as Art 351 (a) of CPC clearly allows judicial review of awards which are wrong in matters of law and fact.

Parties to an arbitration agreement may waive their right of appeal. ${ }^{178}$ According to Art 351(2) of CPC, such waiver would be valid only when made "with full knowledge of the circumstances." 179 This provision is interpreted as prohibiting waiver (of appeal right) in arbitration agreement, since "at the time the agreement was prepared parties could not have had full knowledge of the circumstances". ${ }^{180}$ Practically, however, courts have enforced finality clauses which are waivers of appeal rights beforehand. ${ }^{181}$ Even more, the Federal Supreme Court Cassation Division has recently established a precedent that finality clauses bar otherwise possible review by the Cassation Bench of the Federal Supreme Court. ${ }^{182}$ Hence, wider judicial review of arbitral awards may be denied if parties, in their arbitration agreement, waive their right of appeal.

${ }^{175}$ Ibid.

${ }^{176}$ Most modern arbitration legislations do not permit judicial review of arbitral awards on issues of fact and law; see, e.g., Redfern, supra n. 38, at § 9-44.

177 See, e.g., Re Matt Construction Works Consultants Plc and Tambo International Plc v. Abu Dhabi Establishment, Federal Supreme Court, Civil Appeal Case No.16021/1997[hereinafter Matt Construction] and Re Gebrehiwet Debesai v Fondiaria Fire Insurance Co.( cited in n.153 supra).

${ }^{178}$ Art 350(2), CPC.

${ }^{179}$ Ibid.

${ }^{180}$ Sedler on Procedure, supra n. 82, p. 389.

181 See, e.g., Re Disaster Prevention and Preparedness Commission v Heirs of Ato Feleke Getahun, Federal Supreme Court, Civil Appeal Case No.351/88; Re Getu Geletu v Rina International Investment Ltd, Federal Supreme Court, Civil Appeal Case No.9440/1994; Re National Motors Corp. v General Business Development, Federal Supreme Court Cassation Bench, Cassation File No.21849/1997[hereinafter National Motors Case].

${ }^{182}$ Ibid, National Motors Case. 
Instead of reviewing the arbitral award themselves, courts have sometimes remitted awards for reconsideration by the arbitrators. ${ }^{183}$ Remission, a procedure which enables the arbitrators to cure a certain defect, is however available only where the arbitrators either (1) omitted to decide matters referred to them or (2) erred on matters of law or fact. ${ }^{184}$ Courts cannot remit awards to arbitrators if arbitrator misconduct and procedural irregularities are involved. ${ }^{185}$

Apart from appeals, application for annulment is possible under Ethiopian law. ${ }^{186}$ Yet, the grounds for annulment do not include what in many other jurisdictions are recognised as such. For instance, procedural irregularities and arbitrator misconduct do not constitute grounds for setting aside an arbitral award. Of course, procedural irregularities, along with arbitrator misconduct, may justify appeal from an award. ${ }^{187}$ Nonetheless, issues can be taken with Ethiopian law which allows only appeal, not nullity action, to challenge arbitral awards rendered by, for example, improper conduct of arbitrators. Annulment, rather than judicial review, of awards seems the most sensible remedy for challenges based on grounds such as misconduct of arbitrators and procedural irregularities. ${ }^{188}$ More alarmingly, since parties may contract out of any statutory grounds of appeal, courts could be left without an effective means to enforce mandatory rules on procedural fairness. ${ }^{189}$ This is particularly dangerous as Ethiopian courts are now vigorously enforcing finality clauses. ${ }^{190}$

${ }^{183}$ See, e.g., Matt Construction.

${ }^{184}$ Art 354(1), CPC.

${ }^{185}$ Ibid.

${ }^{186}$ See the discussion in section 3.3 supra.

${ }^{187}$ See Art 351(c)-(d), CPC.

188 The law, perhaps in partial admission of the inappropriateness of the procedure under Art 351 to challenges based on grounds like procedural irregularities, differentiates between two sets of grounds of appeal - grounds (1) that trigger remission and (2) that do not (see n.183-185 supra). It is, however, unclear why the legislator, apparently cognisant of the unsuitability of procedural irregularities and arbitrator misconduct as triggers to procedures related to appeal, failed to further simplify the regime by, for example, including them under the most appropriate list in Art 356. Note that under the UNCITRAL Model Law and many other modern legislations, procedural irregularities and possibly arbitrator misconduct are grounds for setting aside - the only recourse against arbitral awards. See n.91 supra; Art 34, UNCITRAL Model Law; Art. V, New York Convention, Redfern, at §9-34.

${ }^{189}$ In principle, procedural unfairness results in the annulment/setting aside or judicial review of an award (see Art 351 and Art 356, CPC). Yet, as "arbitrator misconduct" and "procedural irregularities" are not specifically mentioned under Art 356 as grounds for annulment, setting aside is not apparently possible. The two are, however, among grounds of appeal from an award under Art 351. Still, parties may contract out the two as grounds of appeal from an award (see Art 350 (2)). In such 
There seems to be some conceptual ambiguity in various Ethiopian court decisions regarding the difference between appeals from arbitral awards vis-àapplications for setting aside arbitral awards. Though the two procedures of challenging awards are different, some courts have erred in taking the setting aside procedure as another procedure justifying judicial review of arbitral awards on the merits. ${ }^{191}$ In my opinion, courts need not review arbitral awards when a party to arbitration applies for annulment/setting aside of an arbitral award. The task of the court called to set aside an arbitral award should be strictly limited to either granting or denying the application for annulment. ${ }^{192}$ Judicial review of arbitral awards with a view to vary, reverse, or even confirm the same is however presupposed when an appeal - based on the grounds listed under Art 351 - lies from an award.

Generally, the practical role of Ethiopian courts in entertaining challenges to arbitral awards is not as negative as their role in dealing with preliminary arbitral matters such as challenges to the jurisdiction of arbitrators. Moreover, as witnessed in National Motors Corporation v General Business Development, Ethiopian courts are moving towards a new direction of enforcing finality clauses, perhaps at the expense of some public policy. ${ }^{193}$ Seen from the perspective of commercial arbitration, however, the courts are less parochial. Arguably, the precedent set in National Motors Corporation v General Business Development may take Ethiopian law to the level of modern arbitration legislations which permit arbitrators to act as amiable compositeure with the

cases, courts may not have excuses to justify either review or annulment of an award rendered (1) by a misbehaving arbitrator or (2) following procedural irregularities. Perhaps, courts may find some way out within the provisions of Art 350(2) that subject the validity of contractual waiver of the right of appeal to a certain condition; but see n.173-174 supra.

190 See n.178-182 supra and the accompanying texts.

191 In Disaster Prevention and Preparedness Commission v Heirs of Ato Feleke Getahun, for example, the Federal Supreme Court reasoned that it would have reviewed the decisions of the arbitrators irrespective of the finality clause had the applicant based its appeal on the grounds mentioned under Art 356, instead of those under Art 351! An identical reasoning is spelt in the judgement of the same court in Getu Geletu v Rina International Investment Ltd. Though the court is correct in holding finality clauses do not waive the right to apply for annulment under Art 356, it is wrong to take the grounds listed under Art 356 as alternative grounds of appeal.

192 Art 357, CPC.

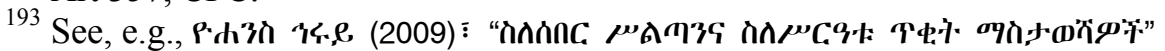

Ethiopian Bar Review, (3)1, pp. 131-148. 
agreement of the parties. ${ }^{194}$ Incidentally, much of the limitations regarding challenge of arbitral awards have to do with the law, not courts.

\subsection{2- Enforcement and Recognition of Awards}

As seen above, commercial arbitral awards rendered by tribunals seated in Ethiopia are generally enforced (without any prior condition) in the same manner as an ordinary court judgement. ${ }^{195}$ Here, we are only concerned with foreign ${ }^{196}$ awards whose enforcement, according to Art 461 of CPC, is subject to some five tests.

Ethiopian law on enforcement of foreign arbitral awards is comparable with the 1958 New York Convention on the Recognition and Enforcement of Foreign Arbitral Awards. In particular, most of the grounds of refusal to enforce under Ethiopian law are similar to those recognised under the Convention. However, the latter unlike the former is pro-enforcement. The phrase in Art 461 CPC which provides that "foreign arbitral awards may not be enforced in Ethiopia unless..." sounds anti-enforcement in the sense that it makes enforcement conditional on the fulfilment (and presumably on the production of evidence to that effect) of all the conditions laid down in the law. ${ }^{197}$ In other words, unlike in most modern arbitration legislations, it seems that foreign arbitral awards are enforceable only exceptionally, ${ }^{198}$ not as a rule.

Art 461 is titled enforcement of foreign awards and omits recognition which, under comparable national and international laws, ${ }^{199}$ is addressed together with enforcement. The omission, coupled with the absence of specific statutory provisions governing the recognition of foreign awards, invites a query

${ }^{194}$ Modern arbitration laws allow amiable compositeur (See Tweeddale \& Tweeddale, supra n. 29, at $\S 9-12$ ). Yet, the status of Ethiopian law regarding amiable compositeur is unclear and, hence, subject to diverse opinion (see, e.g., Tilahun, supra n. 17, p.138, Bezzawork, supra n. 27, p. 80). Given the recent decision of the Federal Cassation's Chilot in National Motors Case, it may however be argued that Ethiopian law allow amiable composition. Crucially, the insistence of Ethiopian courts to honour party agreement excluding judicial review is a strong evidence that courts may tolerate arbitrators who, with the agreement of the parties, acted as ex aequo bono or in equity.

195 See n.95 supra.

${ }^{196}$ Note that "foreign arbitral award" is not necessarily synonymous with "international arbitral award"; see n.28 supra.

197 An ideal pro-enforcement provision would rather, for example, read: "foreign arbitral awards are enforced in Ethiopia unless..." or, like in Art.V of the New York Convention, "recognition or enforcement may be refused only if..."

198 The way Ethiopian courts interpreted this statutory provision affirms this view; see n. 202 infra and the accompanying text.

${ }^{199}$ For example, the 1958 New York Convention. 
whether the provisions of Art 461 apply to recognition of foreign awards as well. The answer to be given, though not always important, ${ }^{200}$ is of particular concern with respect to types of awards which demand only recognition, i.e., which are defensive in nature. Given the absence of separate statutory guidelines on the grounds for refusal of recognition, it would be ideal if courts simply extended the application of the rules on enforcement to cases involving recognition. ${ }^{201}$

Under Ethiopian law, reciprocity is one of the grounds for refusing enforcement of foreign arbitral awards. Moreover, the onus of proving reciprocity is on the applicant as Ethiopian courts have practically declined to presume reciprocity. In the Paulos Papassinus case, ${ }^{202}$ the Federal High Court and, on appeal, the Federal Supreme Court denied an application for enforcement of a certain Greek judgement only because the applicant failed to prove reciprocity, i.e., that Ethiopian judgements are enforced in Greece. As the Ethiopian statutory rules on enforcement of foreign judgements and awards are not mutually exclusive, it is almost certain that the court would reach at similar conclusion vis-á-vis enforcement of foreign awards as well. ${ }^{203}$ In contrast, under the general international practice shaped by the New York Convention ${ }^{204}$ reciprocity plays a meagre ${ }^{205}$ role and the onus of proof is hardly ever on the party seeking enforcement. ${ }^{206}$ After all, reciprocity is not included among the list

${ }^{200}$ As enforcement often presupposes recognition, the omission of the term recognition in Art 461 may not be a big deal in cases where recognition is sought with a view to subsequent enforcement; see, e.g., Ibrahim, Idris (1999) "Ethiopian Law of Execution of Foreign Judgments", Journal of Ethiopian Law, 19, p. 21[hereinafter Ibrahim]; Redfern, supra n. 38, at $\S 10-10-10-12$.

${ }^{201}$ This would make Ethiopian law compatible with the international practice set by the 1958 New York Convention, under which grounds for refusal of enforcement of foreign arbitral awards are equally applicable to cases involving recognition.

${ }^{202}$ In the Matters of Paulos Papassinus, Federal High Court, Civil Case No.1623/1980; and in the Matters of Paulos Papassinus, Federal Supreme Court, Civil Appeal Case No.1769/88. In particular, the courts reasoned that Ethiopian courts are not bound to execute judgements rendered in Greece as there is no treaty of judicial assistance between Ethiopia and Greece.

${ }^{203}$ Particularly, Art 461 (a) expressly cross-refers to Art 458 (a) - the very article on reciprocity exception via-á-vis execution of foreign judgment. Also, Art 461 (2) authorises the analogical application of the provisions on execution of foreign judgments when the enforcement of a foreign award is sought.

${ }^{204}$ As of October 2010, 145 states are members to the New York Convention.

${ }^{205}$ According to leading authorities in international arbitration, reciprocity is rather "becoming a relic"; see Redfern, supra n. 38, at § 10-27.

${ }^{206}$ Art V(1), New York Convention reads "recognition and enforcement of the award may be refused, at the request of the party against whom it is invoked, only if that 
of grounds of refusal of enforcement. ${ }^{207}$ It would be a ground of denying enforcement only if states opt for the reciprocity reservation under Art.I(3). Even then, it may only be invoked against awards rendered in a non-contracting state. ${ }^{208}$ Award from these states, however, may still avoid rejection when, for example, the rendering non-contracting state has a law allowing enforcement of awards rendered in the state where enforcement is sought. In addition, the presumption of reciprocity means foreign awards are in principle enforced, unless a defendant who challenges enforcement pleads and proves that a similar award from the enforcing state would not be enforced in the rendition state. ${ }^{209}$

In denying enforcement for a foreign judgement on grounds of absence of proof of reciprocity, both the High Court and the Supreme Court are hindering the very purpose of reciprocity. ${ }^{210}$ The absence of any presumption that Ethiopian judgements/awards are enforced in a certain foreign state has in effect led to the refusal (by Ethiopian courts) of execution of judgement from a state that would actually allow enforcement of judgments/ awards rendered in Ethiopia. $^{211}$ According to a certain critic, this may have far reaching implications, as it may well result in miscarriages of justice and negative impacts on the economy of Ethiopia:

"[T] he person who has obtained a judgement abroad at considerable expense and inconvenience [would be] subjected to another piece of litigation in Ethiopia on the same facts and issue...[U]nder the current mode of application of the principle by Ethiopian Courts, the mishap is bound to recur almost in every case. This makes the country a safe haven to judgment-debtors against successful litigants... [F]oreign businessmen may [also] avoid entering into transactions with their Ethiopian counterparts or they will simply increase

party furnishes to the competent authority where the recognition and enforcement is sought, proof that...”[emphasis added].

${ }^{207}$ See Art V, New York Convention.

${ }^{208}$ Redfern, supra n. 38, at $\S 10-27$.

${ }^{209}$ After all, Model Law countries recognise and enforce arbitral awards irrespective of reciprocity! See Redfern, supra n. 38, at § 10-27; Arts 35-36, Model Law; and Art V(1), New York Convention.

${ }^{210}$ The main purpose of the reciprocity is to ensure that states enforce judgements and awards rendered in the enforcing state; also, it is maintained that such purposes are not served at the expense of innocent judgement-creditors who seek enforcement of the same (see Ibrahim, supra n. 200, pp. 23-24). The importance attached to this principle is, however, in decline; see n.205 supra.

211 At the time the Ethiopian courts refused enforcement to the Greek judgment, Greece was a party to the New York Convention and had already had a modern law that in principle allows enforcement of Ethiopian judgements and awards; see Campbell, D. \& Campbell, C., eds. (1995) International Civil Procedure. London, Lloyd's of London Press Ltd., p. 357 et seq. 
'the transaction costs of doing business' in Ethiopia by demanding advance payment, guarantee and so on. In both cases, the business initiatives of Ethiopians would be damaged",212

The other downside of refusing enforcement to foreign judgments/awards only because reciprocity is not established relates to the judiciary itself:

"That Ethiopian courts deny res judicata effect to foreign [awards] means that they will retry the case all over again. This surely entails an unnecessary waste of the scarce resources and judicial time on foreign disputes." 213

As a matter of international practice, recognition and enforcement of a foreign arbitral award may be refused if a court in the country (where recognition or enforcement is sought) finds that the subject matter of the difference is not arbitrable under the law of that country. ${ }^{214}$ Inarbitrability (of the matter addressed in a foreign arbitral award) is one of the grounds of refusal of enforcement in Ethiopia as well. ${ }^{215}$ Yet, the uncertainties ${ }^{216}$ on a range of issues involving arbitrability under the Ethiopian legal system make Ethiopia an unsuitable jurisdiction for easy enforcement of foreign awards against administrative agencies, to say the least.

As seen earlier, the Ethiopian jurisprudence on arbitrability of administrative contracts is less than settled. And, government agencies, the most regular Ethiopian participants in international commercial arbitration, have often taken advantage of the situation. ${ }^{217}$ For instance, in Water Supply and Sewage Authority $v$ Kundan Singh Construction Limited, ${ }^{218}$ a government agency successfully moved the High Court of Addis Ababa to deny enforcement of an international arbitral award under the guise of inarbitrability of administrative contractual matters. ${ }^{219}$ On the other hand, the Federal Cassation's Chilot has arguably set a precedent that matters arising out of administrative contracts are arbitrable. $^{220}$ Though the precedent favours the enforcement of foreign and/or

${ }^{212}$ Samuel, Teshale (2000), "Reciprocity with Respect to Enforcement of Foreign Judgements in Ethiopia: A Critique of the Supreme Court's Decision in the Paulos Papassinuos Case", The African Journal of International and Comparative Law, 12, pp. 573-574.

213 Ibid.

${ }^{214}$ Art V(2)(a), New York Convention.

${ }^{215}$ Art 461(1)(e), CPC.

${ }^{216}$ See the discussion in Section 4.1 above. Also, see Zekarias, supra n. 107, p. 120 et

seq.

${ }^{217}$ Ibid.

${ }^{218}$ See supra. n.106

${ }^{219}$ See supra n.107 and the accompanying text; see also Zekarias, supra n. 107, p. 120.

${ }^{220}$ See n.111-115 supra and the accompanying texts. 
international awards relating to administrative contracts, the actual impact of the newly set precedent is yet to be seen.

\section{Concluding Remarks}

States benefit from an efficient regime of commercial arbitration. This is mainly because, the arbitral settlement of disputes better suits the business community by reducing the transaction costs of trade involving individuals, property, and business situated in different jurisdictions thereby facilitating trade and investment. Cognisant of this and other benefits of arbitration, numerous states including Ethiopia - have put in place regimes that facilitate the utilisation of this alternative dispute settlement scheme.

As arbitration involves dispute settlement by private judges lacking public authority, the involvement of national courts is crucial to the overall efficacy of the process. However, the intervention of courts in this private dispute settlement process needs to be modest and consistent with the interest of the parties to relieve themselves from prolonged and costly judicial dispute settlement.

The role of courts in Ethiopia appears to be more than modest. Although they play a positive role in, for example, enforcing valid arbitration agreements and finality clauses, Ethiopian courts have generally assumed extended roles with regard to commercial arbitration which is supposed to function with minimal court intervention. In this regard, they are obviously assisted by the national arbitration law which, inter alia, licences (1) premature judicial intervention during arbitral proceedings; (2) broader judicial review of awards except when parties preclude the same through, for example, finality clauses; and (3) overstringent thresholds (which are nearly equivalent to refusal) in the enforcement of foreign arbitral awards.

It is submitted that courts should rather adopt an approach that fosters efficient arbitral settlements in local and international commercial disputes as Ethiopia normally benefits, rather than loses, from the same. A permanent solution would, however, likely be legislative rather than judicial, since the law appears particularly handy in developing jurisprudence hostile to commercial arbitration. Particularly, the statutory rules that allow wider interlocutory judicial review of application for disqualification along with the rules that tolerate broader judicial review of arbitral awards must be updated with a view to minimising judicial intervention in arbitration. Moreover, the antienforcement rules of Art 461 of CPC indeed require review so as to facilitate easier enforcement of foreign arbitral awards in Ethiopia. Finally, the Ethiopian law on the setting aside of arbitral awards vis-à-vis an appeal from arbitral awards should be revised so as to provide courts with effective means of enforcing procedural fairness. 